I notice these all show the G. Russet at the stem end. I have seen the blossom end Russet. I may say the whole tree does not produce all like the sample, since the Russet predominates. The fruit is not as large as it should be, for the trees lack the necessary culture."

The account given in this letter does not agree altogether with that given in Mr. Clarke's earlier letter, as to the parent varieties. The earlier account stated that Boston Stripe grafted on a seedling gave rise to the parent tree; in this account Boston Stripe is the stock and Golden Russet the scion. It is impossible at present to decide between the two accounts. The photograph shows very well the sharply marked division of the apples into regions very different in appearance. The stem end of the apple was in each case of "russet" and without stripes; the blossom end was smooth skinned, of a light red color striped with yellow or green (uncolored). When one of the apples was cut open the flesh was found to be different in texture and flavor in the two regions. Underneath the russet skin the flesh was coarser grained. One end of the apple was distinctly sour, the other insipid, almost sweet, but I neglected to note which region was sour, the russet or the striped portion, but I think the former. The line of demarcation within the flesh was sharp, as on the surface.

Since the time when these "freak" apples first came to my attention the nature and origin of such plant creations has been investigated with brilliant success by Winkler and Baur in Germany. As a result we now call such things plant-chimeras, and we know that they arise in consequence of grafting, in cases wherein the original buds of the scion have failed to grow, but an adventitious bud has arisen exactly at the junction of stock and scion and including cells derived from both. Each of these two kinds of cells reproduces its own sort, though they remain side by side but quite distinct in the same stem.

Winkler has produced several different sorts of chimeras by grafting the tomato (Solanum lycopersicum) and the nightshade ( $\mathrm{S}$. nigrum) one upon the other and then decapitating the graft. In some of these the stem is divided right and left between tomato and nightshade tissue, the stem on one side bearing tomato leaves, on the other nightshade leaves. Such plants are known as sectorial chimeras. In other cases, tomato cells form the one or two outer layers of the entire plant, while underneath occur only nightshade cells; or these relations may be exactly reversed. Histological study fully confirms this view. Such chimeras are known as periclinal.

In the apples figured the chimera would seem to be sectorial rather than periclinal, if the line of demarcation ran lengthwise of the apple rather than across it. But as it is, they resemble more a periclinal chimera which has everted its deeper lying tissue at the blossom end of the fruit. Does the fruit of the apple develop in that way? Will such fruits give us a clue to the answer? They certainly merit further study.

\title{
Galton's Law of Regression
}

The law of regression tells heavily against the full hereditary transmission of any gift. Only a few out of many children would be likely to differ from mediocrity as widely as their mid-parent, and still fewer would differ as widely as the more exceptional of the two parents. The more bountifully the parent is gifted by nature, the more rare will be his good fortune if he begets a son as richly endowed as himself, and still more so if he has a son who is endowed yet more largely. But the law is even handed; it levels an equal succession tax on the transmission of badness as of goodness. If it discourages the extravagant hopes of a gifted parent that his children will inherit all his powers, it no less discountenances extravagant fears that they will inherit all his weakness and disease.-Francis Galton: Natural Inheritance (1889). 